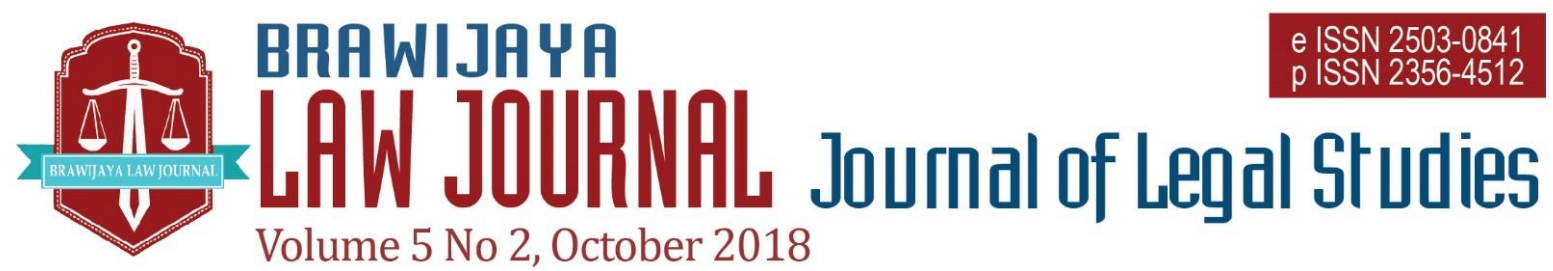

Nationally Accredited No. 32a/E/KPT/2017 Dated 26th April 2017

This work is licensed under a Creative Commons Attribution-NonCommercial 4.0 International License

\title{
Recent development of Civil Procedural Law in Thailand: the Class Action and the Legal Execution
}

\author{
Pornchai Wisuttisak ${ }^{1}$ \\ ${ }^{1}$ Chiang Mai University \\ Email: pornchai.w@cmu.ac.th
}

Submitted : 2018-06-30 | Accepted : 2018-10-24

\begin{abstract}
Abstract: The paper aims to study on the overview of civil procedural law in Thailand with emphasis on the recent amendment regarding to class action and legal execution. The civil procedural law in Thailand, known as Procedural Use of Civil and Commercial Codes Act 1937 was passed in 1938 as to formulate the trail, execution of judgment, and appeal in civil and commercial codes. The civil procedural law in Thailand became a vital legal rules governing a proper civil trial and judgments. This Thailand Civil Procedural Law was recently amended on the provisions of class action and the efficiency of the legal execution. It is argued that such amandment create vital impact to legal practices on civil procedurals in Thailand. The amendment helps to modernize the rules for class action and facilitates the process on legal execution in Thailand. Adopting juridical normative method with statute approach, this paper submitted that civil procedural law should be amended throughfuly and not only partialy to keep up with the rapid changes on civil and commercial cases. To achieve this, more amandments of Procedural Use of Civil and Commercial Codes Act 1937 need to be done.
\end{abstract}

Keywords: civil procedural law, Thailand, legal execution, class action, civil and commercial codes

\section{INTRODUCTION}

The Thai Civil Procedural Law is based on the Procedural Use of Civil and Commercial Codes Act 1937 (BE 2477) (hereinafter Civil Procedural Act). ${ }^{1}$ The Act lays down procedural rules for applying Thai Civil and Commercial Codes 1924 (BE 2466). ${ }^{2}$ Thus, in deciding any civil and commercial cases, Thai court judges have to consider both the civil procedural law and the civil and commercial codes. The Thai Civil Procedural Act contains civil procedural rules in 4 main Chapters. The first Chapter is a general rules on civil procedure. The second chapter lays down the rules on process of deciding cases under court of first instance. The third chapter states legal rules on the Appellate court decision and the Supreme Court decision. The fourth chapter set out legal rules regard to specific methods

1 Procedural Use of Civil and Commercial Codes Act 1937 (BE 2477) 
prior to the legal execution after court decision.

In order to address rapid changes. Especially changes in modern technology such as transformations on digital economy, e-business practices and e-contractual arrangements, it is submitted that the Thai Procedural Law needs to be adjusted. The adjustment of the law was done by the amandment of the laws, especially on the provisions regarding class action and legal execution. It is argued that . The amendment helps to modernize the rules for class action and facilitates the process on legal execution in Thailand. This paper aims to analyse the amandment of Thai Procedural Law with emphasis on the recent amendment regarding to class action and legal execution. This paper proceed with the overview of Thailand Civil Procedural Law and followed by the analyses of its amandment whether such amandment are sufficient enough to address rapid development of technology.

\section{LEGAL MATERIALS AND METHODS}

This paper uses normative juridical methodology, which based on primary aterials that is Thailand laws, especially on civil procedure. Secondary materials were also used in this research, which include books, academic journal and other academic resources. Internet resoures is also important in this research since the revision took place relatively recently. The primary materials mention previously include Procedural Use of Civil and Commercial Codes Act 1937 and its revision, which was done in 2017.

\section{RESULTS AND DISCUSSIONS The Framework of Procedural Use of Civil and Commercial Codes Act 1937}

In this section, the framework of Procedural Use of Civil and Commercial Codes Act 1937 will be firstly elaborated. It is a very comprehensive legal framework setiing out the civil procedural Acts and commercial codes. It consists of four main chapters and several appendixes which include appendix relates to court fees, fee for investigation to witness outside court room, fee all necessary cost for the court process, and fee for the legal execution. Each of the chapter will be elaborated briefly in this section.

In the first chapter ${ }^{3}$, there are rules regarding to general legal definition, court jurisdiction, objection to judge who decide the case, panels of the judges, and report with case detail. The first chapter also contains legal right of persons in civil cases, filing case, proofs and evidence, and court decision and order. Thus, the first chapter tends to contains most of the vital rules governing civil case in the court. In the context of the court jurisdiction, the case usually be sued in the court of justice which deals with civil commercial and civil case. In Thailand, there are three main courts; the Courts of Justice, Administrative courts, and the Military Court. The Courts of justice is the designated court which hear dispute and cases on civil and commercial codes.

In additional, in the first chapter section 55 , any person or juristic person according to the Thai Civil and Codes have his/her right to pursue legal cases in the Court of justice. Two persons or more are able to jointly request court to consider case, if the persons would have benefit from the cases result. ${ }^{4}$

4 Procedural Use of Civil and Commercial Codes Act 1937 (BE 2477) section 59 
Judges in deciding any case will have to consider reliable evidences which are documents and/or person witness. However, judges may not consider the evidence in case there are general truths or the facts on which both disputing parties have already accepted.

Picture 1: Court of Justice Thailand ${ }^{5}$

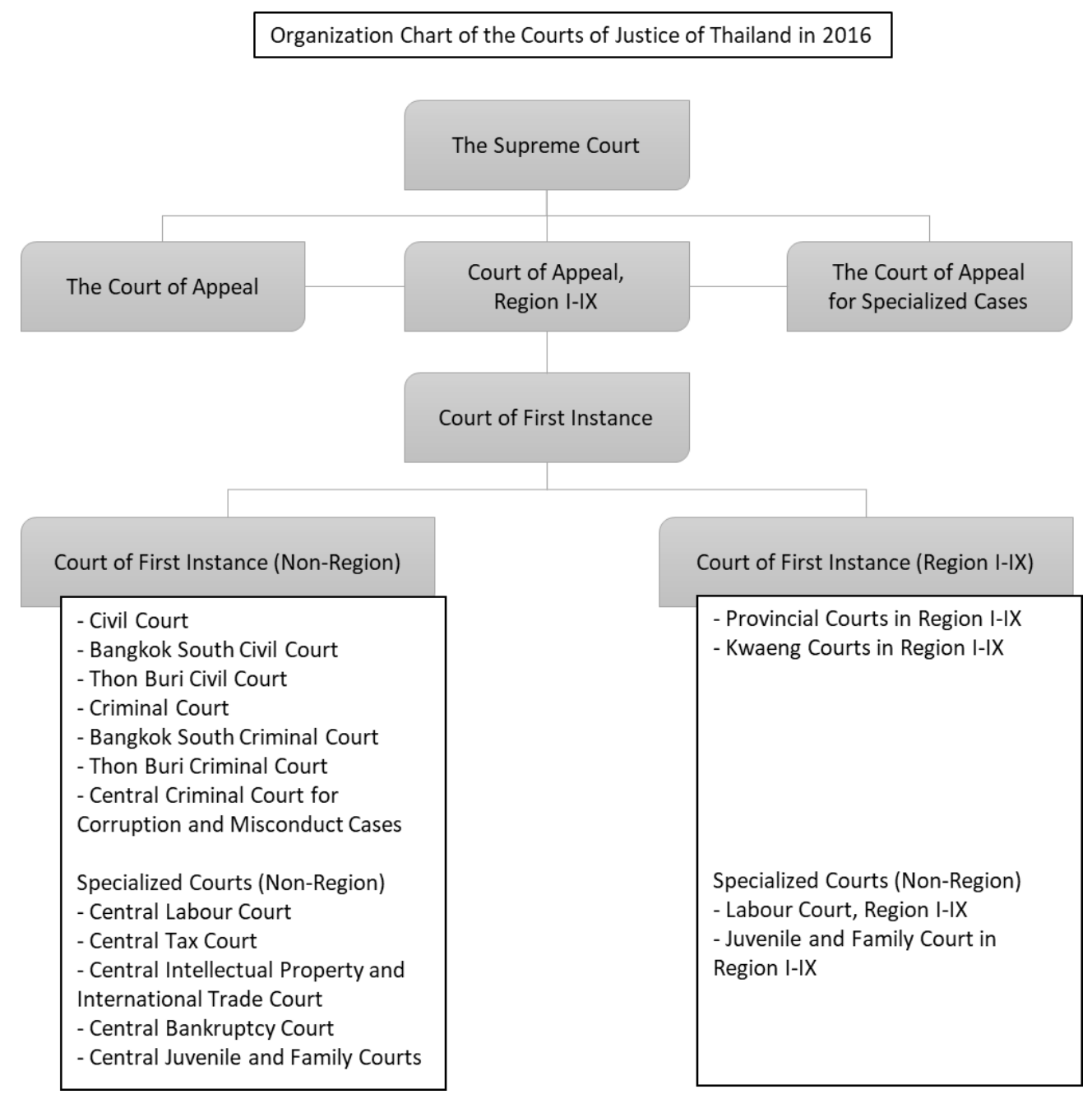

In the second chapter 6 , there are procedural rules of court of first instance. The judge in the court of first instance, when considering any case, must strictly apply the second chapter in civil and commercial cases. The judges have to apply legal rules of normal civil procedures in court of first instance and in some cases have to apply special civil procedures. The special civil procedures relate to legal

procedures of petty cases. The chapter also state rules on the process of deciding case without defendants in case that the defendants do not attend the court procedure. When person would like to sue civil and commercial case to the court, the person initiate his/her case in court of first instance. ${ }^{7}$ The plaintiff will have to prepare clear legal document and submit the

5 Court of Justice Thailand, 2017, Structure of Courts of Justice,

$<$

http://www.coj.go.th/en/cojstructure.html>

6 Procedural Use of Civil and Commercial Codes Act 1937 (BE 2477) section 170-222

7 Procedural Use of Civil and Commercial Codes Act 1937 (BE 2477) section 170 
documents to the court of first instance. ${ }^{8}$ After receive a case request from the plaintiff, court will issue a copy of the case to defendant within 7 days. ${ }^{9}$ During the case process, the plaintiff is prohibited to submit multiple but same case to the court. The plaintiff is entitled to request to the court to remove the case from the case procedure. ${ }^{10}$

The third Chapter set out the procedural rules for appealing case to the Court of Appeal and to the Supreme Court. After the decision from the court of first instance, the plaintiff or defendant are permitted to submit the decision to the appeal court. ${ }^{11}$ However, if the case involve financial dispute less than ThB 50,000, the appeal on the cases must be not be on the fact of the case, except the incident that one judge of the panel in the court of first instance have noted on the unclear fact of the case. ${ }^{12}$ If there is an appeal regarding to the fact of the case, the appeal on the fact must be of significant to the case. ${ }^{13}$ In case any person intend to submit the appeal to the court of appeal, the appeal must be within 1 month after the court of first instant has decided the case. ${ }^{14}$ The appeal do not constitute a release to the execution of decision from the court of first instance. ${ }^{15}$ Nevertheless, the person who appeal the case is able to submit to the court of appeal to give injunction order to the execution of decision from the court of first instance. ${ }^{16}$ The court of appeal after consider all

8 Procedural Use of Civil and Commercial Codes Act 1937 (BE 2477) section 175

9 Procedural Use of Civil and Commercial Codes Act 1937 (BE 2477) section 173

10 Procedural Use of Civil and Commercial Codes Act 1937 (BE 2477) section 175-176

11 Procedural Use of Civil and Commercial Codes Act 1937 (BE 2477) section 223

12 Procedural Use of Civil and Commercial Codes Act 1937 (BE 2477) section 224

13 Procedural Use of Civil and Commercial Codes Act 1937 (BE 2477) section 225 documents submited from both legal parties will be able to decide the appeal case by the way of "(i) if the appeal court considers that the appeal is prohibited by procedural rules, the court may dismiss the appeal, (ii) if the court of appeal considers that the decision from the court of first instance is correct, the court of appeal may upheld the decision from the court of the first instance, (iii) if the court of appeal disagrees with the decision from the court of first instance, the court of appeal may make a new decision for the case, (iv) if the court of appeal considers the decision from the court of first instance is partly correct, the court of appeal may partly upheld the case and provides additional decision as to correct the previous decision." 17

In an event that the party does not agree with the decision from the court of appeal, the party may apply to the Supreme Court within 1 month from the Court of appeal's decision. The party must request for an approval to appeal case from the Supreme Court by submitting the appeal. ${ }^{18}$ If the Supreme Court approve the appeal, the court must decides the case as soon as possible. The Supreme Court may approve the appeal of the case by consideration on "(i) the issue of the case relates to public benefit, (ii) the decision from the court of appeal conflicts with precedency of the previous Supreme Court decisions, (iii) the decision from the court of appeal has no

14 Procedural Use of Civil and Commercial Codes Act 1937 (BE 2477) section 229

15 Procedural Use of Civil and Commercial Codes Act 1937 (BE 2477) section 231

16 Procedural Use of Civil and Commercial Codes Act 1937 (BE 2477) section 231

17 Procedural Use of Civil and Commercial Codes Act 1937 (BE 2477) section 242

18 Procedural Use of Civil and Commercial Codes Act 1937 (BE 2477) section 247 
precedent decision from the Supreme Court decision, (iv) the decision from the court of appeal conflicts with other court decisions, (v) the aims to develop the interpretation of laws and (vi) important problems set by the President of the Supreme court"19

The fourth Chapter envisages rules regarding to specific methods prior to the legal execution after court decision. By the rules, the court has power to make execution of the court decision and has power to decide any method for execution set out by laws. ${ }^{20}$ If there is a court decision, court must execute the decision at the time that the decision has been made and that the party who loses the case become the debtor according to the court decision. ${ }^{21}$ If the court decision obligates the debtor to pay an amount of money or to give properties or to stop any actions, the decision must set out clear execution and clear timeframe to be complied by the decision. ${ }^{22}$ In case that the decision is on the petty case, court may not set out timeframe to act according to the decision. But the debtor in the petty case must comply with the court decision within 15 days after the decision. ${ }^{23}$ If party who lose the case does not act according to the court decision, the win party may request the court to legally seize property or freeze property as to pay the win party according to the court decision. ${ }^{24}$ The department of the legal execution under Ministry of Justice will have to enforce their power as to obligate the debtor to pay or to act according to court

19 Procedural Use of Civil and Commercial Codes Act 1937 (BE 2477) section 249

20 Procedural Use of Civil and Commercial Codes Act 1937 (BE 2477) section 271

21 Procedural Use of Civil and Commercial Codes Act 1937 (BE 2477) section 272

22 Procedural Use of Civil and Commercial Codes Act 1937 (BE 2477) section 273

23 Ibid decision. ${ }^{25}$ The officer of the department of the legal execution will have power when the debtee requests debtor to pay or to act according to court decision. ${ }^{26}$ The officer of the department of the legal execution must collect money or control properties with due care in order to transfer them to the debtee according to court decision. ${ }^{27}$

In addition to the four main chapters, Thai Civil Procedural Act sets out appendix tables which relate to court fees, fee for investigation to witness outside court room, fee all necessary cost for the court process, and fee for the legal execution. Thus, based on the four main chapters and the appendix tables, Thai Civil Procedural Act is very comprehensive legal rules for processing case on civil and commercial disputes in the court.

\section{Recent development of Thai Civil Procedural Law}

As the first part of the paper provides overview of legal frameworks of the civil procedural law, this second part of the paper aims to discuss on the recent development of the civil procedural law relating to; 1 ) the revision for the class Action and 2) the revision to create efficiency of the legal execution.

\section{Revision for the Class Action}

The Thai Civil Procedural Act was amended in 2015 as to significantly create a procedural rules for Class Action. The amendment is to permit class action legal

24 Procedural Use of Civil and Commercial Codes Act 1937 (BE 2477) section 274

25 Procedural Use of Civil and Commercial Codes Act 1937 (BE 2477) section 274; See information about the legal execution department at <http://www.led.go.th/default.asp>

26 Procedural Use of Civil and Commercial Codes Act 1937 (BE 2477) section 278

27 Ibid 
proceedings in Thailand. The amendment is to fill legal gap in civil procedures that did not recognize class action lawsuits in legal proceedings. Thus the amendment marks a vital development in the Thai court system. ${ }^{28}$ The amendment to the legislation was to develop Thai legal procedure of class actions similar to jurisdictions such as the United States but there are some different in context of Thai law. ${ }^{29}$

The amendment to the Civil Procedural Act is mainly on section 222 that set out rules for class action. The amendment on section 222 defines people groups for legal procedure as a people who shares legal right, based on same fact and law. In order to proceed any legal action under a class action, there must be an approval from the court. ${ }^{30}$

In requesting the court to approval any class action in court procedure, the case must be that the group of people has common legal ground on "tort, breach of contract and legal right to claim any damages from environmental law, labor protection law, security law, and competition law" 31 The groups of people to proceed any legal action to the court must conjointly submit to the court that they would like to pursue the court case under class action procedure. ${ }^{32}$ If the court approve the class action of the group, the court may ask the group to pay assurance fee within 7 days. In case that there is no payment of the assurance fee, the court may disapprove the class action. ${ }^{33}$

28 Tilleke \& Gibbins, 2015, "Class Action Legal Proceedings Now Available in Thailand", $<$ http://www.tilleke.com/resources/class-actionlegal-proceedings-now-available-thailand >

29 Ibid

30 Procedural Use of Civil and Commercial Codes Act 1937 (BE 2477) section 222/1

31 Procedural Use of Civil and Commercial Codes Act 1937 (BE 2477) section 222/8

32 Procedural Use of Civil and Commercial Codes Act 1937 (BE 2477) section 222/9
The members of the class action are able to opt-out the group by giving written notice to the court within 45 days of case proceeding. ${ }^{34}$ The person who have given written notice to the court to opt-out the class action group will not be able to return to the group of class action. ${ }^{35}$ Additionally, the person who leave the class action group will not be able to pursue legal case on the same legal ground of the class action. ${ }^{36}$ Once court make a case decision, the plaintiff may only appeal as a group of class action and the individuals do not have appeal rights. ${ }^{37}$

The examples of the class action allow in the amendment of the Thai Civil procedure are on the case that there are significant damages or injuries to general public and people. The damaged and injured people may collectively claim to the court by the class action as to demand compensation for their damages or injuries. Another example is where there are breaches of contracts by company limited or public companies, listed in Thai Stock exchanges, the consumers who suffered from the breach are able to collectively resort to class action as a legal procedure to demand compensation from the breach.

According to Ratanachaichan, the initial plan to amend the Civil Procedural Act on the class action was initiated by the Stock Exchange Commission. The objective of the amendment is to protect wide investors and consumers in the Thai

33 Procedural Use of Civil and Commercial Codes Act 1937 (BE 2477) section 222/14

34 Procedural Use of Civil and Commercial Codes Act 1937 (BE 2477) section 222/15(6)

35 Procedural Use of Civil and Commercial Codes Act 1937 (BE 2477) section 222/16

36 Procedural Use of Civil and Commercial Codes Act 1937 (BE 2477) section 222/18

37 Procedural Use of Civil and Commercial Codes Act 1937 (BE 2477) section 222/45 
Stock Exchange from the fraudulent public company. ${ }^{38}$ The benefits to the class action in the Thai Civil Procedural act are the lower cost of proceedings, the efficiency in facilitating justice to a larger group of the society, the protection to the interests of the less privileged in society and parties suffering from minor damages by providing a means of securing compensation. ${ }^{39}$ Thus, the amendment of the Thai Civil Procedural Act is boon to create better legal procedural rules as to develop protection of wide public interests.

\section{Revision to create efficiency of the legal execution}

Chapter four of the Thai Civil Procedural Act was amended in July 2017. The main aim of the amendment is to create effective legal execution of the court decision. The amendment to the Thai Civil Procedural Act was amended on the section 271-367 relating to authoritative power of the officer in legal execution ${ }^{40}$ and properties which are not under legal execution- The important is that there is no legal execution to the debtor salary less than ThB 20,000 ${ }^{41}$ Other legal execution include seize of property after the court decision, ${ }^{42}$ freeze of property right after the court decision, ${ }^{43}$ request for property distribution, ${ }^{44}$ sell of the property under legal execution, ${ }^{45}$ establishment of

38 Ratanachaichan, C. 2013, A Primer on the Draft Law on Class Action, < https://www.aseanlawassociation.org/9GAdocs/ Thailand.pdf>

39 Ibid

40 Procedural Use of Civil and Commercial Codes Act 1937 (BE 2477) section 297

41 Procedural Use of Civil and Commercial Codes Act 1937 (BE 2477) section 301

42 Procedural Use of Civil and Commercial Codes Act 1937 (BE 2477) section 303

43 Procedural Use of Civil and Commercial Codes Act 1937 (BE 2477) section 316 management on property instead of sell of the property ${ }^{46}$ and execution by ejectment ${ }^{47}$

The above lists are only some example of major revision on the Thai Civil Procedural Act in 2017. There are complex and numerous details of amendments. The paper aims not to include all details of the revision but to presents that the amendment will create effectiveness for legal execution according to the court decision. Before the amendment in 2017, there were complaints about process of legal execution which is very slow and difficult. The amendment clarifies and fastens process of legal execution, so the execution will be more effective.

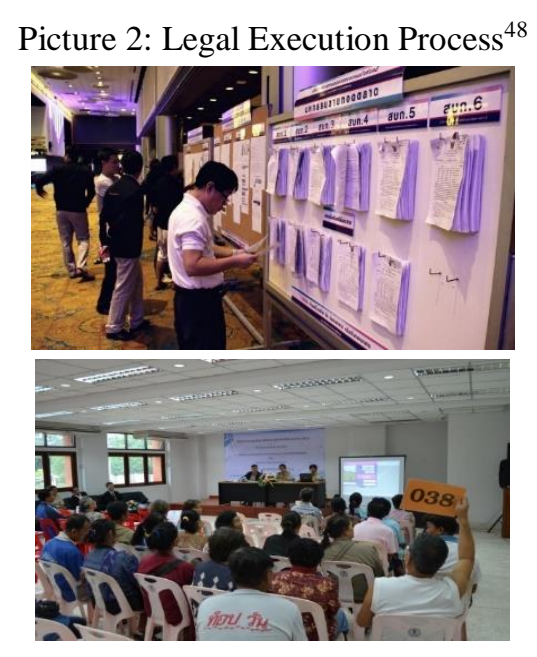

According to Ruamridee, the director of the department of legal execution, the new revision on the Thai Civil Procedural Act on legal execution can lead to overall development of the legal execution process

44 Procedural Use of Civil and Commercial Codes Act 1937 (BE 2477) section 326

45 Procedural Use of Civil and Commercial Codes Act 1937 (BE 2477) section 331

46 Procedural Use of Civil and Commercial Codes Act 1937 (BE 2477) section 336

47 Procedural Use of Civil and Commercial Codes Act 1937 (BE 2477) section 350

48 Thairath News, <https://www.thairath.co.th/ content/831209>, and Office of legal execution, Skornankorn province, <http://sub.led.go.th/ sawangdandin/index.php/all-infomation/5-201307-25-03-25-14.html> 
in Thailand. ${ }^{49}$ The revision creates effective by 1)clarification of methods to execution of properties, 2) increase power of officer conducting legal execution, 3) remove all unnecessary process of legal execution, and 4) improvement of sell of properties under legal execution. Thus, in over all the amendment build up an efficient process for legal execution according to court decision.

\section{CONCLUSIONS AND SUGGESTIONS}

The first part of the paper present the general frameworks of Thai legal procedure base on the Thai Civil Procedure Act. The Act was passed on 1938 and has various amendments up until 2017. The Act seems to be comprehensive and helps facilitate the legal procedure linking to trails procedure, court decision and legal execution of cases on civil and commercial codes. Lawyers, legal practitioners, and legal academics are able to follow the fundamental legal procedure of the Thai Civil Procedure Act. Thus, in overall, the Thai Civil Procedure Act formulate civil procedural to create high standard of legal procedure in Thailand. The second part of the paper then focuses on the recent amendment which create a major changes to Thai civil procedure. The changes are on the inclusion of class action in Thai Civil procedure and the transformation of legal prosecution toward effective process. The inclusion of class action benefits public and consumers in case they collectively pursue court case with corporates. The transformation of sections of the Thai Civil Procedure on legal execution helps fasten and clarify process of legal prosecution to all public. Thus the recent major changes show that at least Thailand has it interest to build up better

49 Ruamridee, S, 2017, "Department of Legal Execution clarify on the new amendment", Thai standard of civil procedure. The development make sure that the civil procedure show a bright side of modernization of law in Thailand. With regards to the new class action procedure, consumers would be able to collectively act against the unfair corporates and cooperatively protect them from unfair business practices. The change elevates a legal obstructions for consumers who have less financial and legal power in Thailand's justice system. With regards to the new legal prosecution, the legal officers and people would have faster process of obtaining their legal rights after a court decision. The changes also increase awareness to people who face severe financial difficulty. The change at least gives people a chance to financially survive and to financially revive back again.

Nevertheless, the manner of amendments on the Thai Civil Procedure tends to base on the fixing on legal issues only case by case basis. Since the enactment of Thai Civil Procedure in 1938, it has been 30 amendments to the act. Each of amendments tends to focus on the legal issue keeping up with business economic and social changes. With the consideration that the Thai Civil procedures should be an efficient legal mechanism to facilitate all necessary legal procedure, the paper suggest that there should be an overhaul amendments to the act and to create better formation of the Thai civil procedure. Therefore, it should be a set policy for modernization on Thai civil procedure law in order to keep up with various rapid transformations on digital economy, ebusiness practices and e-contractual arrangements in Thailand. 


\section{REFERENCES}

\section{Books}

Office of the State of Thailand,

Comparison on Old and New Civil

Procedural Rules (2017)

$<$ http://web.krisdika.go.th/data/outsit

edata/outsite4/file/31-8-60.pdf>

Ratanachaichan, C. A Primer on the Draft

Law on Class Action, (20130) <

https://www.aseanlawassociation.org/

9GAdocs/Thailand.pdf>

Sonvoravongsa, K., Class action for

Initial Public Offering of Securities

(Durakij Bundit University, 1999)

Sukothaithammatirat, Civil law 1

(Thailand, 2014)

Tilleke \& Gibbins, Class Action Legal

Proceedings Now Available in

Thailand (2015)

<http://www.tilleke.com/resources/cl

ass-action-legal-proceedings-now-

available-thailand>

Wayupap, P., Explanation Legal

Procedural Rules in Consumer Cases

(Krung Siam Publishing, Bangkok, 2016)

Wayupap, P., Legal Procedural Rules

(Legal Book publishing, Bangkok,

2008)

\section{Journal Articles}

Pichiansoontorn, Y., 'Class Action in Competition Law: The Problems of Counsels for Plaintiff' (2018) 71

Thammasat Business Law Journal

\section{Internet Materials}

Piriyapanyaporn, C., 2018, Thailand Legal Update: Incoming Class Action Law

- Section 222/8 of the Civil

Procedure Code,

$<$ https://www.dfdl.com/resources/leg

al-and-tax-updates/thailand-legal-

update-incoming-class-action-law/ >

Ruamridee, S, 2017, “Department of Legal

Execution clarify on the new amendment", Thai Ministry of

Justice News on19 July 2017, <

http://www.moj.go.th/view/9991>

\section{Thesis/ Disertation}

Meeboonsang, N., 2008, Class Action In

Environmental Case, Master Thesis,

Chula Longkorn University,

<http://cuir.car.chula.ac.th/bitstream/

123456789/859/3/Namtaee.pdf >

\section{Act/ Legislation}

Procedural Use of Civil and Commercial Codes Act 1937 (BE 2477)

Procedural Use of Civil and Commercial Codes Act 1937 (BE 2477) (Revision in 2017) 